\title{
Philo's Argument for Divine Amorality Reconsidered
}

\section{Klass J. Kraay}

Ryerson University

digital.library.ryerson.ca/object/31

Please Cite:

Kraay, K. J. (2003). Philo's argument for divine amorality reconsidered. Hume's Studies, 29(2), 283-304.

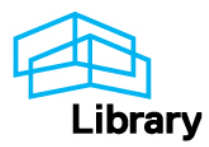




\section{PHILO’S ARGUMENT FOR DIVINE AMORALITY RECONSIDERED}

Klaas J . Kraay

Ryerson University

This paper appears in Hume Studies 29 (2003): 283-304. The published version can be found online at: http://www.humesociety.org/hs/issues/v29n2/kraay/kraay-v29n2.pdf

'You seem not to apprehend, replied Philo, that I argue with Cleanthes in his own way; and by showing him the dangerous consequences of his tenets, hope at last to reduce him to our opinion."

(DNR 2.11; 145)

A central tactic in Philo's criticism of the design argument is the introduction of several alternative hypotheses, each of which is alleged to explain apparent design at least as well as Cleanthes' analogical inference to an intelligent designer. In Part VI, Philo proposes that the world "...is an animal, and the Deity is the soul of the world, actuating it, and actuated by it" (DNR 6.3; 171); in Part VII, he suggests that ".. it is a palpable and egregious partiality" to favour reason as a probable cause of apparent design over other principles such as instinct, generation, vegetation, and "... a hundred others which lie open to our conjecture” (DNR 7.11; 178); and in Part VIII, he offers an 'Epicurean' hypothesis according to which the appearance of design is due to matter itself. ${ }^{1}$ It is widely agreed that by the end of Part VIII, Philo has convincingly shown that the empirical evidence considerably underdetermines the conclusion Cleanthes purported it to establish. Philo, at any rate, declares a sceptical triumph: "A total suspense of judgement is here our only reasonable resource" (DNR 8.12; 186-7).

Philo's swift argument for divine amorality at the end of Part XI contrasts markedly with this scepticism. ${ }^{2}$ Here, Philo reasons with great confidence concerning what he takes to be the (only) four hypotheses concerning the morality of the first cause(s) of the universe: divine benevolence, divine malevolence, Manicheeism, and divine amorality. He argues briefly against the first, summarily rejects the second and third, and declares with apparent sincerity that "[t]he true conclusion is, that the original source of all things is entirely indifferent to all these principles, and has no more regard to good above ill than to heat above cold, or to drought above moisture, or to light above heavy" (DNR 11.15; 212).

I first discuss Philo's argument for divine amorality, and I distinguish it from his earlier criticisms of any inference from mundane data to divine benevolence. In Section 2, I diagnose deficiencies in two contrary interpretations of the argument for divine amorality. In Section 3, I offer three reasons for rejecting the surface meaning of this argument. In Section 4, I reveal Philo's argument to be a sophisticated parody of both Cleanthes' natural theology and his appeal to the passional influence of the design hypothesis. Philo, I argue, does not intend to show that the Deity is probably amoral; rather, he intends to show Cleanthes - by literally arguing with him "in his own way" (DNR 2.11; 145) - that the tools of Cleanthes' 'experimental theism' can equally be wielded in service of a wholly incompatible view. 


\section{Philo on EVIL}

Before arguing for divine amorality in Part XI, Philo first claims that the moral qualities of the Deity cannot be concluded, from mundane data, to resemble human moral qualities. After surveying the variety of human misery in Part X, Philo challenges Cleanthes:

And it is possible, Cleanthes ... that after these reflections, and infinitely more, which might be suggested, you can still persevere in your anthropomorphism, and assert the moral qualities of the Deity, his justice, benevolence, mercy, and rectitude, to be of the same nature with these virtues in human creatures? His power we allow infinite: Whatever he wills is executed: But neither man nor any other animal are happy: Therefore he does not will their happiness. His wisdom is infinite: He is never mistaken in choosing the means to any end: But the course of nature tends not to human or animal felicity: Therefore it is not established for that purpose. Though the whole compass of human knowledge, there are no inferences more certain and infallible than these. In what respect, then, do his benevolence and mercy resemble the benevolence and mercy of men? (DNR 10.24; 198.)

Although it may seem that Philo here means to argue for the logical incompatibility of evil with God's existence, there are compelling textual reasons to think that Philo intends merely to block any empirical inference to the attribute of benevolence. First, all participants in the Dialogues agree throughout that the existence of God is not up for dispute, but only his attributes. Second, Philo explicitly interprets his argument as concerning only the attribute of benevolence at $\$ 24$, \27, \35 of Part X, and Cleanthes responds within these parameters at \$31. Third - and still

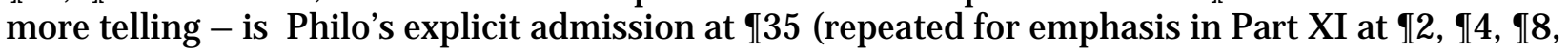
and \12) of the "possible compatibility" of God's benevolence (and hence existence) with evil. And, finally, there is the specific wording of \$36, where Philo concludes triumphantly that "...there is no view of human life, or of the condition of mankind, from which, without the greatest violence, we can infer the moral attributes, or learn that infinite benevolence, conjoined with infinite power and infinite wisdom, which we must discover by the eyes of faith alone" (DNR 10.36; 202). So, the intent of the main argument of Part $X$ is to block any empirical inference from mundane evidence to the benevolence of the Deity. ${ }^{3}$

While Part X concerns the benevolence of an infinite Deity, Part XI treats Cleanthes' hypothesis of a benevolent, finite Deity. Philo again urges that divine benevolence cannot be concluded from the mundane data, which suggest that there are four circumstances of evil, none of which "... appear to be to human reason, in the least degree, necessary or unavoidable; nor can we suppose them such, without the utmost license of imagination" (DNR 11.5; 205). ${ }^{4}$ Thus, since divine goodness has not been established a priori, it "... must be inferred from the phenomena, [and] there can be no grounds for such an inference, while there are so many ills in the universe, and while these ills might so easily have been remedied, as far as human understanding can be allowed to judge on such a subject" (DNR 11.12; 211).

At this stage in the Dialogues, Philo has completed a persuasive argument for the difficulty of inferring divine benevolence from mundane evidence. Philo the sceptic would stop here, and conclude that empirical evidence is insufficient to warrant any conclusion concerning the moral attributes of the Deity. Surprisingly, however, Philo does not do this. In Part XI, ๆ1316, Philo mounts an extremely uncharacteristic positive argument for the amorality of the Deity. ${ }^{5}$ Philo begins by noticing certain unpleasant features of the world: the hostility, destructiveness, and unhappiness of creatures. From these observations, Philo concludes that "[t]he whole presents nothing but the idea of a blind nature, impregnated by a great vivifying principle, and pouring forth from her lap, without discernment or parental care, her maimed and abortive children" (DNR 11.13; 211). 
Philo next considers several alternative hypotheses to divine amorality. Having already thoroughly rejected the view that divine benevolence can be inferred from the world, he next turns to Manicheeism. To dispose of this view, Philo appeals to the "perfect uniformity and agreement of the parts of the universe" (DNR 11.14; 211) and the "the uniformity and steadiness of general laws" (DNR 11.15; 212). Since no combat between good and evil can be detected in all this regularity, Manicheeism may safely be discounted. ${ }^{6}$ Philo next considers divine malevolence, but he claims that this view cannot be supported by the "mixed phenomena" found in the world (DNR 11.15; 212). By elimination, then, Philo concludes that divine amorality is the most probable hypothesis: "The true conclusion is, that the original source of all things is entirely indifferent to all these principles, and has no more regard to good above ill than to heat above cold, or to drought above moisture, or to light above heavy" (DNR 11.15; 212).

\section{TWO CONTRARY INTERPRETATIONS OF THE ARGUMENT FOR DIVINE AMORALITY}

In a well-known article, Nelson Pike holds that - appearances notwithstanding - Philo remains a sceptic about the moral properties of the Deity in Part XI:

I think the center of Philo's remarks in this passage must be located in their skeptical rather than their metaphysical import. Philo has proposed a hypothesis that he claims is counter to the one offered by Cleanthes. And he claims that his hypothesis is the "true conclusion" to be drawn from the observed data. But the point is not, I think, that Philo's new hypothesis is true, or even probable. The conclusion is, rather, that the hypothesis advanced by Cleanthes is false, or very improbable. When claiming that evil in the world supports a hypothesis that is counter to the one offered by Cleanthes, I think Philo simply means to be calling attention to the fact that evil in the world provides evidence against Cleanthes' theological position. ${ }^{7}$

Stanley Tweyman takes the opposite view, and characterizes Philo's method in Parts X and XI as "hypothetico-deductive" rather than sceptical:

In the first eight sections, Philo argues against Cleanthes' hypothesis by advancing his own hypotheses. His effort to advance hypotheses must be assessed in light of the fact that (by his own admission) all such hypotheses are based on insufficient data, and, therefore, none is strictly speaking acceptable. Their use is not to establish truths about the nature of God, but to establish the conclusion which we find at the end of Part VIII that 'a total suspense of judgement is here our only recourse'. The design of the world is compatible with, and could have arisen from, an indefinite number of designing principles. On the other hand ... in dealing with Cleanthes' hypotheses [of divine benevolence] in Parts X and XI we are able to proceed more scientifically, and, in this manner, eliminate all but one of the hypotheses which can be introduced to explain the design of the world. ${ }^{8}$

Tweyman holds that in Parts X and XI, Philo repeatedly tests Cleanthes' hypotheses of natural theology against the relevant empirical evidence, and finds the hypotheses wanting. In Part X, Philo "shows that the only world which can be inferred from Cleanthes' hypothesis [of an infinite benevolent Deity] is one containing only good, and therefore, no evil," and in Part XI Philo continues to use the "hypothetico-deductive" model to argue against Cleanthes' hypothesis of a finite benevolent Deity, against Manicheeism, and for the conclusion of divine amorality. ${ }^{9}$

Pike's interpretation is motivated by the crucial observation that "...many of the criticisms of Cleanthes' position which Philo advanced earlier in the Dialogues would apply with 
equal force to the inference [to divine amorality] Philo just offered". ${ }^{10}$ So Pike's reading of Philo as a sceptic in Part XI is motivated by a desire to render Philo methodologically and philosophically consistent. ${ }^{11}$ But Pike does not account for the strong appearance that Philo intends to urge a positive conclusion in Parts X and XI, since he merely discounts this evidence in order to render Philo consistent. On the other hand, Tweyman's interpretation is specifically designed to account for this appearance, but it appears to leave Philo vulnerable to the charge of inconsistency. ${ }^{12}$ If an interpretation could be found both to account for the appearance that Philo intends to draw a positive conclusion and to defend Philo against the charge of philosophical inconsistency, this, ceteris paribus, would be preferable, given that Philo is Hume's chief spokesman in the Dialogues. ${ }^{13}$ Just such an interpretation will be offered in Part 4 . First, however, I offer some motivation for rejecting the surface meaning of the argument for divine amorality.

\section{Motivation FOR REJ ECTING THE SURFACE MEANING OF THE ARGUMENT}

Philo's argument for divine amorality contains both an inference from mundane data to the moral character of the Deity, and a rejection of alternative hypotheses that purport to explain the data. But earlier in the Dialogues, Philo chides Cleanthes for making a similar inference from observations of the world to the character of the Deity, and he castigates Cleanthes for his arbitrary unwillingness to consider alternative explanations. In 3.1. and 3.2., I argue that Philo's argument in Part XI is inconsistent with these earlier attacks on Cleanthes, and I suggest that this inconsistency provides prima facie reason for doubting the sincerity of Philo's argument for divine amorality. In 3.3., I offer evidence from Part XII that suggests that Philo's true view is not that the Deity is probably amoral.

\subsection{A CLUE FROM PART V}

In Part V, Philo points out some "inconveniences" of Cleanthes' "experimental theism" (DNR 5.1, 5.2; 165). This method, Philo argues, can neither establish divine infinity, nor divine unity, nor divine perfection. Regarding divine perfection, Philo claims that “...were this world ever so perfect a production, it must still remain uncertain, whether all the excellencies of the work can be justly attributed to the workman" - even an excellently produced ship may be the work of a stupid mechanic who merely follows instructions (DNR 5.7; 167). In other words, Philo forbids any inference from the apparent goodness of the world to the goodness of the Deity. Yet in Part $\mathrm{XI}$, he is prepared to make precisely the same kind of inference, in this case an inference from certain features of the world to the amorality of the Deity. So, if Philo intends this latter argument seriously, he violates his own earlier methodological stricture, since he offers no reason for supposing that the inference to divine amorality is relevantly different from the inference to divine perfection. ${ }^{14}$

\subsection{CLUES FROM PART VI-VIII}

In Parts VI-VIII, Philo introduces a series of explanatory hypotheses, each of which (he suggests) can account for apparent design at least as well as Cleanthes' theism. Since each hypothesis satisfactorily explains the data, Philo argues, it is sheer prejudice to endorse any one. In Part VI, Philo suggests that "The world ... is an animal, and the Deity is the soul of the world, actuating it, and actuated by it" (DNR 6.3; 171). He next suggests that Cleanthes should not dismiss this hypothesis out of hand:

Here therefore is a new species of anthropomorphism, Cleanthes, on which you may deliberate; and a theory which seems not liable to any considerable 
difficulties. You are too much superior surely to systematical prejudices, to find any more difficulty in supposing an animal body to be, originally, of itself, or from some unknown causes, possessed of order and organization, than in supposing a similar order to belong to mind (DNR 6.6; 171-2).

More generally, Philo claims that he would never willingly "defend any particular system of this nature" (DNR 6.12; 174), and his reason is that experience is insufficient to establish any such system: "All these systems, then, of scepticism, polytheism, and theism, you must allow, on your principles, to be on a like footing, and that no one of them has any advantages over the others. You may thence learn the fallacy of your principles" (DNR 6.13; 175).

In Part VII, Philo makes the same point more emphatically. He introduces a variety of outlandish hypotheses concerning the origin of the world, and, when Demea objects that these are "wild, arbitrary suppositions" (DNR 7.7; 177), Philo's reply is forceful:

Right, cries Philo: This is the topic on which I have all along insisted. I have still asserted, that we have no data to establish any system of cosmogony. Our experience, so imperfect in itself, and so limited both in extent and duration, can afford us no probable conjecture concerning the whole of things (DNR 7.8; 177).

Shortly thereafter, Philo sums up his case:

In this little corner of the world alone, there are four principles, reason, instinct, generation, vegetation, which are similar to each other and are the causes of similar effects. What a number of other principles may we naturally suppose in the immense extant and variety of the universe, could we travel from planet to planet and from system to system, in order to examine each part of this mighty fabric? Any one of these four principles above (and a hundred others which lie open to our conjecture) may afford us a theory, by which to judge of the origin of the world; and it is a palpable and egregious partiality, to confine our view entirely to that principle, by which our own minds operate ... Now that vegetation and generation, as well as reason, are experienced to be principles of order in nature, is undeniable. If I rest my system of cosmogony on the former, preferably to the latter, it is at my choice. The matter seems entirely arbitrary (DNR 7.11, 7.14; 178-9).

Finally, in Part VIII, Philo proposes his Epicurean' hypothesis, and claims that it too can account for apparent design. Philo then announces his sceptical triumph:

All religious systems, it is confessed, are subject to great and insuperable difficulties. Each disputant triumphs in his turn; while he carries on an offensive war, and exposes the absurdities, barbarities, and pernicious tenets of his antagonist. But all of them, on the whole, prepare a complete triumph for the sceptic; who tells them, that no system ought ever to be embraced with regard to such subjects: For this plain reason, that no absurdity ought ever to be assented to with regard to any subject. A total suspense of judgment is here our only reasonable resource. And if every attack, as is commonly observed, and no defence, among theologians, is successful; how complete must be his victory, who remains always, with all mankind, on the offensive, and has himself no fixed station or abiding city, which he is ever, on any occasion, obliged to defend? (DNR $8.12 ; 187-8)$. 
With respect to the cause of apparent design in the universe, then, Philo emphatically maintains that reason cannot support any particular hypothesis exclusively.

Things seem very different, however, with respect to the morality of the first cause(s) of the universe. Philo does seem willing, in Part XI, to reject three hypotheses in favour of divine amorality. This is surprising, given Philo's earlier insistence that reason is ill-equipped for such matters. ${ }^{15}$ There need not be an inconsistency here, provided that Philo offers an argument for why our intellectual abilities are superior in this arena. But no such argument is given. Indeed, it is difficult to imagine how Philo could consistently offer such an argument, given his earlier scepticism. And so it seems - on a surface reading of the argument for divine amorality - that the Philo of Part XI is guilty of the same systematical prejudice, the same egregious partiality, that he earlier diagnosed in Cleanthes.

Of course, this sense of inconsistency could, in principle, be mitigated. Were Philo's argument for divine amorality (and his arguments against divine benevolence, divine malevolence, and Manicheeism) compelling, it would be much easier to overlook the methodological tension between his scepticism in Parts VI-VIII and his confidence in Part XI. But, Philo's argument is simply not persuasive. Yandell points to two deficiencies:

The "four hypotheses" are not exhaustive, even if we read "first causes" as "first cause or causes". Suppose that there are two causes. Both might be mainly good, or mainly evil, or one mainly good and one mainly evil. These possibilities are simply ignored though supposedly all possibilities had been included. Further, these hypotheses are compatible with "mixed phenomena," and explain them at least as well as the preferred hypothesis. The argument, then, is surprisingly weak - indeed, the reasoning is sloppy in a way unusual for Philo. ${ }^{16}$

Other possible hypotheses are also ignored. Perhaps, for example, there are many causes, ranging from exceedingly good to exceedingly evil, and each is responsible for just some of the 'mixed phenomena' observed in the world. The fact that Philo - who earlier developed so many alternative design hypotheses with ease - is here unable to offer more than four alternatives strongly suggests that the surface meaning of the text is misleading.

Philo's hasty rejection of Manicheeism is also surprisingly unpersuasive. Philo thinks that this hypothesis cannot account for " the perfect uniformity and agreement of the parts of the universe" (DNR 11.14; 211). But just a few paragraphs earlier, Philo complains that the springs and principles of the universe are insufficiently regulated: "...it must be observed, that none of these parts or principles, however useful, are so accurately adjusted, as to keep precisely within those bounds in which their utility consists; but they are, all of them, apt, on every occasion, to run into the one extreme or the other" (DNR 11.11; 210). Surely the Manicheean system could adequately explain these observations. Dale Jacquette also finds fault with Philo's dismissal of Manicheeism:

... Philo's rejection of [Manicheeism] is premature and improperly motivated ... why should Hume or Philo assume that an opposition of good and evil natures in the intelligent design or designers of the universe would necessarily manifest itself in a discordance of natural laws? Why should good and evil fight each other in the first place? And if they do, why not in the souls of men, where something like a conflict of good and evil is often experienced anyway? ... On the contrary, the possibility presented [by this hypothesis] seems more clearly to correspond to the expected result of the analogical inference involved in the argument from design. If like effects have like causes, then the cause of order in the universe ought to have a moral nature relevantly similar to the moral nature of the cause of order in human inventions - a mixture of good and evil. Hume's or Philo's 
attempt to refute the proposition is unsatisfactory, and reveals a surprising inconsistency in the application of the principles. ${ }^{17}$

Philo's swift argument for divine amorality is not, then, satisfactory. ${ }^{18}$ Were it compelling, it would be easier to dismiss the methodological tension that exists between Philo the sceptic of Parts VI-VIII, and Philo the confident natural atheologian of Part XI, ๆ15-16. As things stand, however, this tension requires explanation. I will argue in Part 4 that this tension can be eased by rejecting the surface meaning of Philo's argument for divine amorality, and I will suggest that there are compelling textual reasons to do so.

\subsection{A CLUE FROM PART XII}

A third reason for doubting the sincerity of Philo's argument for divine amorality is found in Part XII. Here, Philo candidly offers his true opinion that belief ought to be suspended on this question. He tells Cleanthes that if God were ".. disposed to be offended at the vices and follies of silly mortals, who are his own workmanship," then philosophical theists (like Cleanthes) would merit favour for entertaining or endeavouring to entertain "suitable notions of his divine perfections" (DNR 12.32; 226-7). But Philo then notes that the philosophical sceptics (like himself) would be entitled to divine compassion and indulgence, since sceptics "... from a natural diffidence of their own capacity, suspend, or endeavour to suspend all judgement with regard to such sublime and such extraordinary subjects" (DNR 12.32; 227). It cannot be doubted that this represents Philo's 'unfeigned sentiments', and as such it is utterly inconsistent with Philo's confident conclusion in Part XI that the Deity is probably amoral. ${ }^{19}$

\section{Philo’s PARody UNMASKed}

There is, then, prima facie motivation to reject Tweyman's view that Philo's argument for divine amorality is sincere. But what, then, does Philo mean to show by arguing for divine amorality? In what follows, I argue that Philo intends to parody Cleanthes, thereby showing him that his methods can be pressed into the service of hypotheses contrary to his natural theology. By describing Philo's tactic as 'parody', I do not mean to suggest that Philo intends to ridicule Cleanthes. I claim, rather, that Philo insincerely adopts Cleanthes' methods in order to show him a further inconvenience of his experimental theism. ${ }^{20}$

\subsection{THE PARODY OF CLEANTHES' INFERENCE TO DESIGN}

As noted, the moral attributes of the Deity are discussed in Part V. Here, Philo urges that Cleanthes cannot infer divine perfection from the mundane order, given the "many inexplicable difficulties in the works of nature" (DNR 5.6; 166). So far, Philo's point merely anticipates his extended argument for the same conclusion in Parts X and XI. But the relevant passage also foreshadows Philo's argument for amorality in a revealing way.

You have no reason, on your theory, for ascribing perfection to the Deity, even in his finite capacity; or for supposing him free from every error, mistake, or incoherence in his undertakings. There are many inexplicable difficulties in the works of nature, which, if we allow a perfect Author to be proved a priori, are easily solved, and become only seeming difficulties, from the narrow capacity of man, who cannot trace infinite relations. But according to your method of reasoning, these difficulties become all real; and perhaps will be insisted on, as new instances of likeness to human art and contrivance (DNR 5.6; 166-7, emphasis added). 
In the emphasized portion of this passage, Philo warns Cleanthes that his method can be turned against him. J ust as Cleanthes wants to appeal to certain features of the natural world to support his theism, so too one could insist that other features of the natural world support an entirely different conclusion: divine amorality. ${ }^{21}$ And if Cleanthes thinks himself entitled to dismiss alternative explanatory hypotheses, then the atheologian could consider himself similarly entitled. As we have seen, this is exactly what Philo does in Part XI.

Philo also telegraphs his intentions to Cleanthes in Part X, when, after introducing Epicurus' old questions, he briefly endorses the design inference, but only to make a point about evil: 22

You ascribe, Cleanthes (and I believe justly) a purpose and intention to nature. But what, I beseech you, is the object of that curious artifice and machinery, which she has displayed in all animals? The preservation alone of individuals and propagation of the species. It seems enough for her purpose, if such a rank be barely upheld in the universe, without any care or concern for the happiness of the members that compose it. No resource for this purpose: No machinery, in order merely to give pleasure or ease: No fund of pure joy and contentment; No indulgence without some want or necessity accompanying it. At least, the few phenomena of this nature are overbalanced by opposite phenomena of still greater importance (DNR 10.26; 198).

An awareness of Philo's strategy begins to dawn on Cleanthes: he asks whether Philo has at last betrayed his true intentions (DNR 10.28; 199). Cleanthes does not yet see, however, how Philo will later appropriate the tools of experimental theism.

Turning to Part XI itself, we see the beginnings of this appropriation in I3. Here, Philo argues, analogically, that one is entitled to appeal to the awkward features of the world when forming a hypothesis concerning the character of the designer:

Did I show you a house or palace, where there was no one apartment convenient or agreeable; where the windows, doors, fires, passages, stairs, and the whole economy of the building were the source of noise, confusion, fatigue, darkness, and the extremes of heat and cold; you certainly would blame the contrivance, without farther examination. The architect would in vain display his subtilty, and prove to you, that if this door or that window were altered, greater ills would ensue. What he says, may be strictly true: The alteration of one particular, while the other parts of the building remain, may only augment the inconveniences. But still you would assert in general, that, if the architect had had skill and good intentions, he might have formed such a plan of the whole, and might have adjusted the parts in such a manner, as would have remedied all or most of these inconveniences. His ignorance, or even your own ignorance of such a plan, will never convince you of the impossibility of it. If you find many inconveniences and deformities in the building, you will always, without entering into any detail, condemn the architect (DNR 11.3; 204-5).

This analogical defence of Philo's entitlement to draw conclusions about the moral character of the Deity from mundane evidence is crucial to the success of his argument for divine amorality. ${ }^{23}$ But, Philo earlier chastised Cleanthes for just such a procedure. His very first criticism of Cleanthes' argument from design in Part II was that the analogy between human contrivance and the design of worlds is weak: "...wherever you depart, in the least, from the similarity of the cases, you diminish proportionably the evidence; and may at last bring it to a very weak analogy, 
which is confessedly liable to error and uncertainty" (DNR 2.7; 144). To make this case, Philo points to the dissimilarity between the universe and a house:

If we see a house, Cleanthes, we conclude, with the greatest certainty, that it had an architect or builder; because this is precisely that species of effect, which we have experienced to proceed from that species of cause. But surely you will not affirm, that the universe bears such a resemblance to a house, that we can with the same certainty infer a similar cause, or that the analogy is here entire and perfect. The dissimilitude is so striking, that the utmost you can here pretend to is a guess, a conjecture, a presumption concerning a similar cause; and how that pretension will be received in the world, I leave you to consider (DNR 2.8; 144, emphasis added).

If in Part XI \3 Philo seriously intends to argue analogically using the very same example his earlier self decried in Part II, then he is guilty of inconsistency. ${ }^{24}$ But notice Cleanthes' reply in Part II:

It would surely be very ill received, replied Cleanthes; and I should be deservedly blamed and detested, did I allow that the proofs of a Deity amounted to no more than a guess or conjecture. But is the whole adjustment of means to ends in a house and in the universe so slight a resemblance? The œeconomy of final causes? The order, proportion, and arrangement of every part? Steps of a stair are plainly contrived, that human legs may use them in mounting; and this inference is certain and infallible. Human legs are also contrived for walking and mounting; and this inference, I allow, is not altogether so certain, because of the dissimilarity which you remark; but does it, therefore, deserve the name only of presumption or conjecture? (DNR 2.9; 144-5).

Since Cleanthes has so vigorously defended this particular analogy in Part II, it now becomes clear what Philo's point is by reintroducing it in Part XI. Philo is parodying Cleanthes' analogical argumentation, thereby showing him that if he persists in ignoring the objections and reasoning from analogy with such conviction, parity will demand that he infer the amorality of God from the mundane evidence.

On this view, it becomes much easier to interpret $\$ 13$ of Part XI. This paragraph immediately follows the conclusion of what I have termed the first stage of Philo's reasoning; the stage which merely seeks to block any empirical inference to the benevolence of the Deity. But the cautious, sceptical tenor of $\uparrow 12$ is nowhere found in $\uparrow 13$ :

Look 'round this universe. What an immense profusion of beings, animated and organized, sensible and active! You admire this prodigious variety and fecundity. But inspect a little more narrowly these living existences, the only beings worth regarding. How hostile and destructive to each other! How insufficient all of them for their own happiness! How contemptible or odious to the spectator! The whole presents nothing but the idea of a blind nature, impregnated by a great vivifying principle, and pouring forth from her lap, without discernment or parental care, her maimed and abortive children (DNR 11.13; 211, emphasis added).

This passage may be taken to be an explicit parody of Cleanthes statement of the design argument at Part II ๆ5. To be sure, Philo does not here mimic the precise analogical structure of Cleanthes' argument, but he nevertheless engages in natural atheology: he reasons from the empirical data to a particular conclusion about God's moral nature. ${ }^{25}$ His point, then, is not that the Deity is probably amoral, but rather that if mundane evidence is to be used in Cleanthes' 
manner, it can just as easily be pressed into the service of the atheologian. $\$ 14-\$ 16$ round out the parody, for in these paragraphs Philo surveys and rejects a variety of alternative hypotheses to that of divine amorality. J ust as Cleanthes remained unmoved by the profusion of alternative accounts of apparent design (in Parts VI-VIII) and continued to insist dogmatically on his preferred hypothesis, so Philo is prepared to summarily dispose of divine benevolence, Manicheeism, and divine malevolence.

\subsection{The PAROdy of CleANTHes' APPEAL to the PASSIONS.}

The emphasized portion of $\$ 13$ (quoted above) hints broadly at the passional appeal of the inference to divine amorality. This is significant, because Cleanthes had appealed to the subrational force of the argument from design in Part III. ${ }^{26}$ At Part III ๆ 7, Cleanthes exclaims: "Consider, anatomize the eye: Survey its structure and contrivance; and tell me, from your own feeling, if the idea of a contriver does not immediately flow in upon you with a force like that of sensation" (DNR 3.7; 154, emphasis added). The similarity of this passage to the emphasized part of the passage just quoted from Philo is remarkable: in both cases the speaker asserts that a certain idea is ineluctable.

In Part III ๆ8, Cleanthes makes no effort to hide this aspect of his position. Apparently conceding something to Philo's earlier criticisms of his use of analogical argumentation, Cleanthes claims that:

...if the argument for theism be, as you pretend, contradictory to the principles of logic: its universal, its irresistible influence proves clearly, that there may be arguments of a like irregular nature. Whatever cavils may be urged; an orderly world, as well as a coherent, articulate speech, will still be received as an incontestable proof of design and intention (DNR 3.8; 155)

Returning now to Part XI $\$ 3$, we find a remarkably similar point made by Philo in favour of the amorality of the Deity. Philo claims that even if it were true that the architect could not remedy some of the inconveniences of the disagreeable house,

..still you would assert in general, that, if the architect had had skill and good intentions, he might have formed such a plan of the whole, and might have adjusted the parts in such a manner, as would have remedied all or most of these inconveniences. His ignorance, or even your own ignorance of such a plan, will never convince you of the impossibility of it. If you find many inconveniences and deformities in the building, you will always, without entering into any detail, condemn the architect (DNR 11.3; 204-5).

In each case, the relevant passional conclusion is held to be immune to the cavils of abstruse reasoning. Philo is telling Cleanthes that if the natural theologian wishes to retreat from the rigorous standards of analogical argumentation to the supposedly safer ground of passional appeal, the natural atheologian will be right there waiting for him, ready to point out that the passions can just as easily be enlisted to oppose theism. ${ }^{27}$

\section{CONCLUSION}

Pace Tweyman, Philo's argument for divine amorality is incompatible with positions Philo espouses elsewhere in the Dialogues. This argument is at odds with Philo's earlier rejection of Cleanthes' proposed inference from perfection in the world to perfection in the designer. It is methodologically and philosophically inconsistent with his earlier strategy of showing that the 
hypotheses of experimental theism are underdetermined by mundane data. And the surface meaning of the argument cannot be squared with Philo's unfeigned sentiments on the subject in Part XII. So there is significant motivation to reject the surface meaning of the argument. In view of these considerations, one might follow Pike by concluding merely that Hume intends Philo's inference to divine amorality to have sceptical import. But this interpretation requires ignoring the strong appearance that Philo does intend to argue that the Deity is probably amoral.

Both problems can be avoided by interpreting Philo's argument for divine amorality as parody. Moreover, there are significant textual clues that favour just such an interpretation. Thus,

close examination of Part XI reveals that - contrary to what it usually thought - Philo means to parody both Cleanthes' natural theology and his appeal to the passional influence of the design hypothesis. Philo's intent is thus not to show that the Deity is probably amoral, but rather to show Cleanthes that the tools of his 'experimental theism' can equally be wielded in service of a wholly incompatible view. By literally arguing with Cleanthes in his own way, Philo shows Cleanthes that he would do well to ponder his own question: "For to what purpose establish the natural attributes of the Deity, while the moral are still doubtful and uncertain?" (DNR 10:28; 199). 


\section{NOTES}

Ancestors of this paper were presented at the American Philosophical Association Pacific Division Meeting (Albuquerque, NM, April 2000) and the 27th Annual Hume Society Conference (Williamsburg, VA, J uly 2000). I would like to thank my commentators on those occasions: Patricia Easton and Lorne Falkenstein, respectively. Thanks are also due to Donald Ainslie, Beryl Logan, Fred Wilson, and to two anonymous Hume Studies referees, for their helpful comments and suggestions on earlier drafts.

${ }^{1}$ All references to the Dialogues will be given in this manner: dialogue (Part) number, paragraph number; page number (in Norman Kemp Smith's edition).

2 I will refer to this argument as the 'argument for divine amorality', or the 'argument for the amorality of the Deity", even though Philo refers only generally to the "first causes" of the universe in 915 . Philo, after all, agrees with his interlocutors that "...the original cause of this universe (whatever it be) we call God ..." (DNR 2.3; 142).

3 That the argument of Part X is intended only to block any empirical inference to divine benevolence is, I think, the majority position. Norman Kemp Smith urges that Philo ".. limits his present discussion to the question whether the phenomena of good and evil justify the inference to a Deity, whether finite or infinite, with benevolence and other moral attributes" (Hume's Dialogues Concerning Natural Religion (New York: Social Science Publishers, 1948), 119). William Capitan claims that "[t]here is no reason to suppose Hume thought Philo's reasoning [in Part X] disproved anything except that the course of nature was an adequate basis for saying the moral attributes of God are the same as those of humans" ("Part X of Hume's Dialogues," American Philosophical Quarterly 3 (1966): 82-5, 84). J ohn Gaskin says that "[t]he crux of Hume's position rests upon showing - what to many people is only too painfully obvious - that evil of one sort or another does exist in the world in sufficient measure to obstruct the inference to an omnipotent and benevolent god" (Hume's Philosophy of Religion, $2^{\text {nd }}$ ed., (London: MacMillan Press, 1988), 53). Stanley Tweyman also notes that Philo's intention in Part $X$ is "...to show that the existence of evil makes it impossible for us to provide reasonable grounds for the hypothesis of a Designer who is infinite and benevolent" (Dialogues Concerning Natural Religion in Focus (New York: Routledge, 1991), 70). See also William Lad Sessions, Reading Hume's Dialogues: A Veneration for True Religion (Indianapolis: Indiana University Press, 2002), 162-3.

${ }^{4}$ In $96-12$ of Part XI, Philo claims that a benevolent Deity would (a) eliminate pain and fulfill its function by a mere diminution of pleasure; (b) interpose favourably by particular volitions in human affairs rather than conducting the world by general laws; (c) endow us with a greater propensity to industry and labour; and (d) improve the accuracy of the springs and principles of the great machine of nature.

${ }^{5}$ I call this a positive argument because it seeks to establish a particular conclusion, as opposed to his earlier efforts to block Cleanthes' conclusion. The conclusion of Philo's positive argument is that the Deity is probably amoral. It is a positive conclusion because Philo does not simply argue that nothing can be known about the moral character of the Deity: he argues that it can be known that the Deity is probably amoral. (For more on this point, see note 13.)

6 Tweyman offers a more detailed gloss on Philo's rejection of Manicheeism (Dialogues Concerning Natural Religion in Focus, 81-82).

7 Nelson Pike, "Hume on Evil," The Philosophical Review 72 (1963): 180-197, 195-6. He reiterates this point in his expanded essay, "Hume on the Argument from Design," in his Hume: Dialogues Concerning Natural Religion (New York: The Bobbs-Merrill Company Inc., 1970), 201-202.

8 Stanley Tweyman, “Hume's Dialogues on Evil” Hume Studies 13 (1987): 84-5. Although (as will be seen) I disagree with Tweyman on this point, I do accept his characterization of Philo's earlier strategy as Pyrrhonian, and also his views on Hume's use of Pyrrhonism as defended in Scepticism and Natural Belief 
in Hume's Dialogues Concerning Natural Religion (The Hague: Martinus Nijhof Publishers, 1986), Chapter 1.

9 ibid., 79. Tweyman speaks somewhat loosely here, for while Cleanthes is portrayed in Part X as holding that God possesses moral attributes, he does not actually argue that these can be inferred from mundane evidence. On this point, see Pike, Hume: Dialogues Concerning Natural Religion, 183-184.

10 Pike, "Hume on Evil," 195. Pike offers no detailed account of this charge, but I will develop it in Section 3.

11 Tweyman's argument against Pike appears to come down to the observation that while Philo does elsewhere play the Pyrrhonian, “... this [fact alone] does not establish that Philo is a Pyrrhonian throughout the Dialogues, and that he always supports positions in order to argue against the hypothesis advanced by Cleanthes" (Tweyman, "Hume's Dialogues on Evil," 76). While this is true, it is unhelpful, for it does not explain Philo's putative inconsistency.

12 George Nathan makes a related point against Tweyman:

...Tweyman has a problem explaining how Philo can hold one position on the attributes of God in Part X (the mystical incomprehensibility thesis) and then supposedly reverse himself in Part XI to argue for another (the indifference thesis)." ("Comments on Tweyman and Davis, Hume Studies 13 (1987): 98-103, 99).

For further reactions to Tweyman's paper, see Davis, J.W., "Going out the Window: A Comment on Tweyman's 'Hume's Dialogues on Evil'," Hume Studies 13 (1987): 86-97, and Wadia, P., “Commentary on Professor Tweyman's 'Hume's Dialogues on Evil'," Hume Studies 13 (1987): 104-11.

${ }^{13}$ Another way to argue (contra Tweyman) that Philo remains a sceptic in Parts X and XI is to claim that his conclusion of divine amorality itself constitutes a sceptical position. Beryl Logan takes this view, as follows:

Given the presence of mixed phenomena - both goodness and evil in the world - the most probable hypothesis regarding the first cause(s) of the universe is that they have neither goodness or malice. In other words, no claim may be made with respect to the benevolence of first cause(s). Given Cleanthes' analogical argument, goodness and power must be inferred from the available data; as the data do not indicate that evil is remedied where this may be possible, no claim may be made for the Deity's goodness and (finite) power. This is, I submit, a further suspense of judgement with respect to Cleanthes' claim that the Deity is benevolent. The 'proper conclusion' is not that God exists but is limited (as God is unable to prevent evil wherever it occurs), but is that no claim can be made, based on the evidence, with respect to God's benevolence ('Why Hume Wasn't An Atheist: A Reply to Andre," Hume Studies 22 (1996): 193-202.)

While I agree with Logan that the overall force of Philo's argument in Part XI is sceptical, I do not share her view that an argument for Divine amorality constitutes a claim that nothing can be concluded about the moral characteristics of the Deity. To conclude that the Deity is amoral is to conclude that the Deity has no moral attributes, and this is significantly different from the sceptical claim that nothing can be concluded about the Deity's attributes. To argue that an object is colourless is not to say that no claim can be made about the colour of that object. Rather, it is to argue, positively, that the object has no colour.

${ }^{14} \mathrm{~J}$ ust before claiming that the excellencies of a work are not necessarily to be attributed to the workman, Philo sceptically claims that "... it is impossible for us to tell, from our limited views, whether this system contains any great faults, or deserves any considerable praise, if compared to other possible, and even real systems" (DNR 5.6; 167). It might be thought that Philo's enumeration of the four circumstances of evil is inconsistent with this earlier claim, but Philo does takes pains to avoid such inconsistency: 
Shall we say, that these circumstances are not necessary, and that they might easily have been altered in the contrivance of the universe? This decision seems too presumptuous for creatures so blind and ignorant. Let us be more modest in our conclusions. Let us allow, that, if the goodness of the Deity (I mean a goodness like the human) could be established on any tolerable reasons a priori, these phenomena, however untoward, would not be sufficient to subvert that principle; but might easily, in some unknown manner, be reconcilable to it. But let us still assert, that as this goodness is not antecedently established, but must be inferred from the phenomena, there can be no grounds for such an inference, while there are so many ills in the universe, and while these ills might so easily have been remedied, as far as human understanding can be allowed to judge on such a subject" (DNR 11.12; 210-11).

${ }^{15}$ Keith Yandell agrees:

Even more surprising [than Philo's undefended limitation of the hypotheses under consideration to just four] is Philo's willingness to draw conclusions of any sort concerning the cosmic order. He has been maintaining that all such matters are beyond reason's tether. For a moment Philo finds himself able to draw explicit conclusions about whether the cause or causes of cosmic order have morally relevant properties, that is, being good or evil or neither (Hume's "Inexplicable Mystery": His Views On Religion (Philadelphia: Temple University Press, 1990), 269).

16 ibid., 268-269. Sessions makes much the same point in Reading Hume's Dialogues, 174-5. He also notes that Philo's argument proceeds on the undefended assumption that "...if there is evil in the world, the first cause(s) will notice it and be able to do something about it" (175).

17 “Analogical Inference in Hume’s Philosophy of Religion,” Faith and Philosophy 2 (1985): 287-294, 289.

${ }^{18}$ In fairness, it should be noted that other commentators have reacted more favourably to this argument. Gaskin explicitly endorses Hume's conclusion, saying that “...the most probable inference from the phenomena (and I now take it that Hume's fourth possibility is the most probable) is the one which is most radically different from the assumptions of virtually all religious belief; namely, the assumption that the gods are concerned with the affairs of men" (57). Tweyman may also evince a qualified support for this argument when he says that "[t]he most probable conclusion appears to be that the Deity is neither good nor malicious, i.e., that the Deity is indifferent to the good and evil in the world ("Hume's Dialogues on Evil," 83-4). Finally, Paul Draper has updated Hume's argument with Bayesian probability theory in "Pain and Pleasure: An Evidential Problem for Theists," in The Evidential Argument from Evil, ed. Daniel Howard-Snyder, (Indianapolis: Indiana University Press, 1996) 12-30, and also in "Probabilistic Arguments from Evil," Religious Studies 28 (1992): 303-317.

19 Philo may be thought to be speaking candidly here for two reasons. First (and most generally) Part XII evinces a remarkably different tone from the earlier Parts, since Philo explicitly appeals to his "unreserved intimacy" (DNR 12.2; 214) with Cleanthes, and elsewhere indicates that these are his "unfeigned sentiments" (DNR 12.9; 219). Second, the passage in question immediately precedes Philo's final assessment of "the whole of natural theology," and this is invariably taken to be Philo's frank judgement (DNR 12.33; 227-8). Sessions agrees (see his Reading Hume's Dialogues 201, note 41).

The difficult 98 (of Part XII) deserves some comment. Here Philo claims that

... as the works of nature have a much greater analogy to the effects of our art and contrivance, than to those of our benevolence and justice; we have reason to infer that the natural attributes of the Deity have a greater resemblance to those of man, than his moral have to human virtues. But what is the consequence? Nothing but this, that the moral qualities of man are more defective in their kind than his natural abilities. For, as the supreme Being is allowed to be absolutely and entirely perfect, whatever departs most from him departs the farthest from the supreme standard of rectitude and perfection (DNR 12.8; 219). 
Philo's apparent endorsement of divine benevolence in this paragraph might seem inconsistent with his reasoning in Parts X and XI. But, as always when speaking candidly, Philo's words are extremely cautious. The claim of divine benevolence evinced here does not depend on empirical inference from the world, but rather depends on the article of orthodox theology that God "...is allowed to be absolutely and entirely perfect" (DNR 12.8; 219, emphasis added). Philo here speaks as he did in Part II, when he noted that "...the original cause of this universe (whatever it be) we call God; and piously ascribe to him every species of perfection" (DNR 2.3; 142). So Philo is saying no more than what was admitted long before; that God's goodness - if antecedently established - will always be found consistent with natural evil and moral depravity. Thus, 98 of Part XII does not undermine my reading of the argument for divine amorality.

20 I thank an anonymous Hume Studies referee for recommending that I clarify this point.

${ }^{21}$ It is telling, then, that Cleanthes' response in the subsequent paragraph is so weak. Cleanthes, in fact, declines to engage any of Philo's arguments seriously in Part V.

22 On this, see Sessions, Reading Hume's Dialogues, 156-7.

23 It is a defence of the legitimacy of inferring something about the character of the designer from the character of the artefact. Thus, it is crucial to the success of Philo's later argument, from mundane evidence, to divine amorality. Pike, however, suggests that this argument is intended merely to block the inference to benevolence:

Given only a house that is constructed in an inconvenient and ugly fashion, one could not effectively argue that the house was the product of a highly skilled architect. There might be no logical incoherence involved in the claim that the house was constructed by a highly competent architect; but given only the house and no further information, the hypothesis under consideration would be poorly supported, indeed. It is clear that Philo is here calling attention to the weakness of a certain inference (1970, 199-200).

As with Pike's interpretation of the argument for divine amorality, his interpretation of this argument simply ignores the strong appearance that Philo means to endorse a certain kind inference (or, more precisely, that Philo suggests that Cleanthes should endorse such an inference).

${ }^{24}$ I take it that Cleanthes' argument concerning the house in Part II takes the following form:

(1) Apparent design in a house leads us to justifiably believe that the house had an architect or builder.

(2) The universe is similar to a house.

(3) Therefore, apparent design in the universe leads us to justifiably believe that the universe had an architect or builder.

In $₫ 8$, Philo rejects the second premise of this argument. It is very strange, then, to see Philo later (in Part $\mathrm{XI}, \mathrm{\uparrow} 3$ ) arguing in this manner, relying on the same premise:

(1) (Apparently) inconvenient construction in a house leads us to justifiably condemn the architect or builder.

(2) The universe is similar to a house.

(3) Therefore, (apparently) inconvenient construction in the universe leads us to justifiably condemn the architect or builder.

25 Effective parody need not mimic its target in every detail, after all. In any case, the confident tone of the paragraph and the fact that it opens with "Look 'round..." - as does Cleanthes' design argument - both suggest that this is parody. Sessions notices this latter point, and calls Philo's speech "...ironically reminiscent of Cleanthes' earlier design argument" (Reading Hume's Dialogues, 173). 
${ }^{26}$ Sessions notices Philo's “overwrought" language in $₫ 13$, but does not see a parody of Cleanthes' appeal to the passions in Part III. (See Reading Hume's Dialogues, 174.)

${ }^{27}$ Richard White makes a similar point regarding Philo's strategy, although he overemphasizes the degree to which Cleanthes' whole position depends on the passions: "One cannot destroy belief in the religious hypothesis with good arguments, because the belief itself does not actually depend on argument - it is a 'feeling', a truth that is experienced as immediately as if it were 'sensation'. Precisely for this reason, the attack upon God and religion must be oblique and rhetorically inspired" ("Hume's Dialogues and the Comedy of Religion," Hume Studies 14 (1988): 391-407, 393.) 